\title{
Interaksi Antara Daya Tumbuh Benih dengan Pertumbuhan Tanaman Semangka (Citrullus lanatus (Thunb.) Matsum dan Nakai) Pada Pemupukan Organik dan Anorganik
}

\section{Interaction Between The Ability of Seed to Grow with Plant Growth of Watermelon (Citrullus lanatus (Thunb.) Matsum \& Nakai) on Organic and Inorganic Fertilization}

\author{
Nazirwan dan Anung Wahyudi
}

Jurusan Budidaya Tanaman Pangan Politeknik Negeri Lampung

Jln. Soekarno hatta No. 10 Rajabasa Bandar Lampung

\begin{abstract}
The aim of this research to observe and analyze the ability to grow of watermelon seeds in organic and inorganic fertilizers. Observing and analyzing the interaction between the ability to grow of watermelon seeds with plant growth in organic and inorganic fertilizers. Recommend a combination of organic and inorganic fertilizers that provide maximum results. This research was conducted in field of State Polytechnic of Lampung on June until Agustus 2014. This research uses a randomized complete block design (RCBD) with treatment in the form of thiamethoxam, inorganic fertilizers and organic fertilizers, namely: $P 1=0 \%$ organic fertilizer $+100 \%$ inorganic fertilizer; $P 2=25 \%$ organic fertilizer $+75 \%$ inorganic fertilizer; $P 3=$ $50 \%$ organic fertilizer $+50 \%$ inorganic fertilizer; $P 4=75 \%$ organic fertilizer $+25 \%$ inorganic fertilizer; P5 $=100 \%$ organic fertilizer $+0 \%$ inorganic fertilizer. Doses of inorganic fertilizers: Urea $=300 \mathrm{~kg} \cdot \mathrm{ha}^{-1}, S P-36=200 \mathrm{~kg} \cdot \mathrm{ha}^{-1}, \mathrm{KCl}=100 \mathrm{~kg} \cdot \mathrm{ha}^{-1}$. Organic fertilizer: manure (cow manure) $=20$ tons.h $a^{-1}$. Data were analyzed with analysis of variance and if there is a real different treatments followed by LSD test at $5 \%$ level. The results showed that organic and inorganic fertilizer application significantly affected fruit length and fruit weight, but did not significantly affect the ability to grow, main stem length and number of leaves. The length of the longest fruit found in the treatment of inorganic fertilizer application of $75 \%+25 \%$ organic fertilizer (P2). While the weight of the heaviest fruit found in the treatment of organic fertilizer application of $100 \%$ (P5). The highest ability to grow plant found in the treatment of $100 \%$ inorganic fertilizer application (P1), treatment of inorganic fertilizer application 50\% +50\% organic fertilizers (P3), P2 and P5 treatment. The longest length of main stem found in P5 treatment, while the highest number of leaves found in P2 treatment.
\end{abstract}

Keywords: fertilization, organic, inorganic, watermelon

Diterima: 06-10-2015 : disetujui 23-10-2015 



\section{PENDAHULUAN}

Tanaman semangka (Citrullus vulagaris Schrad; Citrullus lanatus (Thunb.) Matsum \& Nakai) merupakan tanaman buah herba yang tumbuh merambat berasal dari Afrika; dalam perkembangannya telah menjadi tanaman penting di daerah tropis maupun subtropis (Whitaker dan Davis, 1962; Mohr, 1986; Ashari, 1995). Dari bagian tanaman yang dapat dimakan, yaitu daging buah mengandung air sebanyak $93,4 \%$, protein $0,5 \%$, lemak $0,1 \%$, karbohidrat $5,3 \%$, serat $0,2 \%$, abu $0,5 \%$ dan vitamin A 70 $\mu \mathrm{g}$ (Ashari, 1995). Sedangkan pada bijinya mengandung 20 - $45 \%$ minyak yang berwarna kuning, 30 - 40\% protein, dan bijinya kaya akan enzim urease.

Di Indonesia luas panen semangka pada tahun 2012 adalah 33.012 ha dengan produksi buah 515.505 ton dan produktivitas hasil 15,62 ton.ha ${ }^{-1}$ (Deptan, 2014). Pada tahun 2012 angka pertumbuhan luas panen semangka $-1,29$, artinya terjadi penurunan luas panen dari 33.445 ha pada tahun 2011 menjadi 33.012 ha pada tahun 2012. Sedangkan angka pertumbuhan produksi maupun produktivitas hasil panen pada tahun 2012 meningkat masing - masing sebesar 3,60 dan 4,96. Hal ini berarti terjadi peningkatan produksi dan produktivitas hasil panen; produksi buah meningkat dari 497.600 ton pada tahun 2011 menjadi 515.505 ton pada tahun 2012 begitu pula produktivitasnya meningkat dari 14,88 ton.ha ${ }^{-1}$ pada tahun 2011 menjadi 15,62 ton.ha ${ }^{-1}$ pada tahun 2012.

Perkecambahan dan perkembangan bibit merupakan periode kritis dalam penanaman benih semangka. Pada saat penyiapan benih sebelum semai faktor suhu dan kelembaban dapat mempengaruhi perkecambahan dan pertumbuhan kecambah (Syukur, 2014). Perlakuan pratanam seperti pada benih padi merupakan salah satu alternatif dalam meningkatkan toleransi suatu varietas/galur terhadap cekaman oksigen. Hasil-hasil penelitian pada sejumlah benih menunjukkan bahwa perlakuan invigorasi benih pratanam (matriconditioning dan osmoconditioning) dapat mempercepat pemunculan radikula, meningkatkan persentase perkecambahn dan laju pertumbuhan, dan perbaikan terhadap pertumbuhan bibit pada kondisi tanah yang tidak menguntungkan. Menurut Khan (1992), invigorasi benih pratanam memperbaiki keadaan fisiologis dan biokimia benih melalui perbaikan metabolik, kemunduran, waktu dan potensi untuk berkecambah. Prinsip matriconditioning dan osmoconditioning adalah mengatur pemasukan air ke dalam benih sehingga pemunculan radikula dapat dicegah untuk beberapa waktu sehingga fase aktivasi berlangsung lebih lama.

Pemupukan adalah pemberian bahan-bahan pada tanah agar dapat menambah unsur-unsur atau zat makanan yang diperlukan tanah secara langsung atau tidak langsung serta merupakan salah satu usaha penting untuk meningkatkan pertumbuhan dan produksi tanaman (Murbandono, 1990). Ada dua jenis pupuk yang dikenal untuk tanaman, yaitu pupuk organik dan anorganik. Pupuk organik adalah pupuk alami yang berasal dari bahan-bahan alam yaitu sisa-sisa tumbuhan atau sisa-sisa hewan, sedangkan pupuk anorganik adalah pupuk sintetis yang dibuat oleh industri atau pabrik (Murbandono, 1990).

Penambahan bahan organik sangat membantu dalam memperbaiki tanah yang terdegradasi, karena pemakaian pupuk organik dapat mengikat unsur hara yang mudah hilang serta membantu dalam penyediaan unsur hara tanah sehingga efisiensi pemupukan menjadi lebih tinggi. Hal ini didukung oleh pendapat Rukmana (1995), bahwa untuk mencapai hasil yang maksimal, pemakaian pupuk organik hendaknya diimbangi dengan pupuk buatan supaya keduanya saling melengkapi. Hegde dan Dwivedi (1993), bahwa pemberian bahan organik ke dalam tanah dapat membantu meningkatkan efisiensi penggunaan pupuk kimia melalui perbaikan sifat fisik, kimia dan biologi tanah serta mempunyai pengaruh nyata pada hasil tanaman. 
Penelitian Sudjianto dan Krestiani (2009), perlakuan pemupukan NPK pada dosis 80 g.tanaman ${ }^{-1}$, memberikan hasil terbaik pada tanaman melon terlihat dari berat buah per tanaman, per petak dan kadar gula tertinggi. Hasil penelitian Ariani (2009), tentang uji NPK (16:16:16) dan berbagai mulsa pada tanaman cabai menunjukkan hasil yang berbeda nyata. Jumlah buah pertanaman dan berat buah pertanaman semakin meningkat dengan semakin tingginya dosis pupuk NPK yang diberikan pada berbagai jenis mulsa.

Penelitian ini bertujuan untuk: (1) mengamati dan menganalisis daya tumbuh benih semangka pada pemupukan organik dan anorganik, (2) mengamati dan menganalisis pertumbuhan tanaman semangka pada pemupukan organik dan anorganik, (3) mengamati dan menganalisis interaksi antara daya tumbuh benih dengan pertumbuhan tanaman semangka pada pemupukan organik dan anorganik, dan (4) merekomendasikan kombinasi pemupukan organik dan anorganik yang memberikan hasil maksimum.

\section{METODE}

Penelitian ini dilaksanakan di Kebun Percobaan Politeknik Negeri Lampung selama 3 (tiga) bulan yaitu pada bulan Juni sampai dengan bulan Agustus 2014. Bahan yang digunakan dalam penelitian ini antara lain: benih benih semangka, pupuk anorganik (pupuk N, P, dan K) dan pupuk organik (pupuk kandang), insektisida (Sevin 85 S, Dursban, Bayrusil), fungisida (Dithane M -45, Benlate 50\%), pasir, kertas koran, abu sekam, jerami kering serta bahan - bahan lain yang diperlukan dalam penelitian.

Penelitian ini menggunakan Rancangan Acak Kelompok (RAK) dengan perlakuan pemberian pupuk anorganik dan pupuk organik, yaitu: $\mathrm{P} 1=0 \%$ pupuk organik $+100 \%$ pupuk anorganik; $\mathrm{P} 2=$ $25 \%$ pupuk organik $+75 \%$ pupuk anorganik; $\mathrm{P} 3=50 \%$ pupuk organik $+50 \%$ pupuk anorganik; $\mathrm{P} 4=$ $75 \%$ pupuk organik $+25 \%$ pupuk anorganik; $\mathrm{P} 5=100 \%$ pupuk organik $+0 \%$ pupuk anorganik. Dosis pupuk anorganik: Urea $=300 \mathrm{~kg} / \mathrm{ha}, \mathrm{SP} 36=200 \mathrm{~kg} / \mathrm{ha}, \mathrm{KCl}=100 \mathrm{~kg} / \mathrm{ha}$. Dosis pupuk organik: pupuk kandang (kotoran sapi) $=20$ ton/ha. Data yang diperoleh dianalisis dengan analisis ragam dan apabila ada perlakuan yang berbeda nyata dilanjutkan dengan uji BNT pada taraf $5 \%$.

\section{HASIL DAN PEMBAHASAN}

Perlakuan pupuk organik, pupuk anorganik dan perbandingan kandungan pupuk organik dan pupuk anorganik menunjukkan pengaruh yang berbeda nyata terhadap panjang buah dan bobot buah tetapi tidak menunjukkan pengaruh yang berbeda nyata terhadap daya tumbuh, panjang batang utama dan jumlah daun umur 2-7 MST, seperti terlihat pada Tabel 1 dan 2.

Pada Tabel 1 dan 2, tampak bahwa penggunaan pupuk anorganik saja seperti pada perlakuan P1 tidak dapat meningkatkan daya tumbuh, panjang batang utama dan jumlah daun secara nyata. Hal ini, seperti diindikasikan oleh panjang batang utama dan jumlah daun terendah dibandingkan perlakuan lainnya. Sedangkan penggunaan pupuk organik, perbandingan kandungan antara pupuk organik dengan pupuk anorganik dapat meningkatkan panjang batang utama dan jumlah daun seperti tampak pada perlakuan P2, P3, P4 dan P5 dibandingkan perlakuan P1 walaupun tidak berbeda nyata untuk semua perlakuan terhadap pertumbuhan tanaman semangka. Hal ini diduga, karena aplikasi pupuk organik, dan aplikasi pupuk organik dengan pupuk anorganik dapat menyediakan unsur hara 
lebih baik dan dalam jumlah yang cukup dibandingkan dengan hanya menggunakan pupuk anorganik. Menurut Sarief (1985) tersedianya unsur hara dalam jumlah yang cukup pada saat pertumbuhan vegetatif, maka proses fotosintesis akan berjalan aktif, sehingga proses pembelahan, pemanjangan dan differensiasi sel akan berjalan lancer juga. Selanjutnya, menurut Setyadmidjaya (1986), nitrogen berperan merangsang pertumbuhan batang yang akhirnya dapat memacu pertumbuhan tanaman.

Tabel 1. Pengaruh pupuk organik dan pupuk anorganik terhadap pertumbuhan dan produktivitas tanaman semangka

\begin{tabular}{|c|c|c|c|c|c|}
\hline Perlakuan & $\begin{array}{c}\text { Daya Tumbuh }^{1)} \\
(\%)\end{array}$ & $\begin{array}{l}\text { Panjang Batang } \\
\text { Utama }^{2)}(\mathrm{cm})\end{array}$ & $\begin{array}{c}\text { Jumlah Daun }^{3)} \\
\text { (helai) }\end{array}$ & $\begin{array}{l}\text { Panjang Buah } \\
(\mathrm{cm})\end{array}$ & $\begin{array}{l}\text { Bobot Buah } \\
\text { (ton/ha) }\end{array}$ \\
\hline P1 & $100.00 \mathrm{a}$ & $222.07 \mathrm{a}$ & $22.56 \mathrm{a}$ & $21.34 \mathrm{~b}$ & $6.48 \mathrm{~b}$ \\
\hline P5 & $100.00 \mathrm{a}$ & $254.67 \mathrm{a}$ & $27.22 \mathrm{a}$ & $22.29 \mathrm{ab}$ & $8.30 \mathrm{a}$ \\
\hline $\begin{array}{l}\text { Nilai } \\
(0,05)\end{array}$ & 16.2049 & 31.6431 & 4.5590 & 1.2171 & 0.4389 \\
\hline
\end{tabular}

Keterangan: Angka-angka yang diikuti oleh huruf yang sama, berbeda tidak nyata menurut uji BNT pada taraf $5 \%$

$\mathrm{P} 1=100 \%$ pupuk anorganik $+0 \%$ pupuk organik

$\mathrm{P} 5=0 \%$ pupuk anorganik $+100 \%$ pupuk organik

$100 \%$ pupuk anorganik $=300 \mathrm{~kg} \cdot \mathrm{ha}^{-1}$ Urea $+200 \mathrm{~kg} \cdot \mathrm{ha}^{-1} \mathrm{SP}-36+100 \mathrm{~kg} \cdot \mathrm{ha}^{-1} \mathrm{KCl}$

$100 \%$ pupuk organik $=20$ ton.ha ${ }^{-1}$ Kotoran Sapi

${ }^{1)}$ Daya Tumbuh 2-7 MST; ${ }^{2)}$ Panjang Batang Utama 2-7 MST; ${ }^{3)}$ Jumlah Daun 2-7 MST

Tabel 2. Pengaruh perbandingan kandungan antara pupuk organik dengan pupuk anorganik terhadap pertumbuhan dan produktivitas tanaman semangka

\begin{tabular}{|c|c|c|c|c|c|}
\hline Perlakuan & Daya Tumbuh $_{(\%)}{ }^{1)}$ & $\begin{array}{l}\text { Panjang Batang } \\
\text { Utama }^{2)}(\mathrm{cm})\end{array}$ & $\begin{array}{c}\text { Jumlah Daun }^{3)} \\
\text { (helai) }\end{array}$ & $\begin{array}{l}\text { Panjang Buah } \\
\text { (cm) }\end{array}$ & $\begin{array}{l}\text { Bobot Buah } \\
\text { (ton/ha) }\end{array}$ \\
\hline $\mathrm{P} 2$ & $100.00 \mathrm{a}$ & $239.60 \mathrm{a}$ & $28.00 \mathrm{a}$ & $23.16 \mathrm{a}$ & $7.41 \mathrm{ab}$ \\
\hline P3 & $100.00 \mathrm{a}$ & 245.48 a & $26.89 \mathrm{a}$ & $20.18 \mathrm{c}$ & $5.74 \mathrm{c}$ \\
\hline $\mathrm{P} 4$ & $88.89 \mathrm{a}$ & $245.36 \mathrm{a}$ & $27.22 \mathrm{a}$ & $21.82 \mathrm{~b}$ & $7.63 \mathrm{a}$ \\
\hline $\begin{array}{l}\text { Nilai } \\
(0,05)\end{array}$ & 16.2049 & 31.6431 & 4.5590 & 1.2171 & 0.4389 \\
\hline
\end{tabular}

Keterangan: Angka-angka yang diikuti oleh huruf yang sama, berbeda tidak nyata menurut uji BNT pada taraf $5 \%$

$\mathrm{P} 2=75 \%$ pupuk anorganik $+25 \%$ pupuk organik

$\mathrm{P} 3=50 \%$ pupuk anorganik $+50 \%$ pupuk organik

$\mathrm{P} 4=25 \%$ pupuk anorganik $+75 \%$ pupuk organik

$25 \%$ pupuk anorganik $=75 \mathrm{~kg} \cdot \mathrm{ha}^{-1}$ Urea $+50 \mathrm{~kg} \cdot \mathrm{ha}^{-1} \mathrm{SP}-36+25 \mathrm{~kg} \cdot \mathrm{ha}^{-1} \mathrm{KCl}$

$50 \%$ pupuk anorganik $=150 \mathrm{~kg} \cdot \mathrm{ha}^{-1}$ Urea $+100 \mathrm{~kg} \cdot \mathrm{ha}^{-1} \mathrm{SP}-36+50 \mathrm{~kg} \cdot \mathrm{ha}^{-1} \mathrm{KCl}$

$75 \%$ pupuk anorganik $=225 \mathrm{~kg} \cdot \mathrm{ha}^{-1} \mathrm{Urea}+150 \mathrm{~kg} \cdot \mathrm{ha}^{-1} \mathrm{SP}-36+75 \mathrm{~kg} \cdot \mathrm{ha}^{-1} \mathrm{KCl}$

$25 \%$ pupuk organik $=5$ ton.ha ${ }^{-1}$ Kotoran Sapi

$50 \%$ pupuk organik $=10$ ton $\cdot \mathrm{ha}^{-1}$ Kotoran Sapi

$75 \%$ pupuk organik $=15$ ton.ha ${ }^{-1}$ Kotoran Sapi

${ }^{1)}$ Daya Tumbuh 2-7 MST; ${ }^{2)}$ Panjang Batang Utama 2-7 MST; ${ }^{3)}$ Jumlah Daun 2-7 MST

Penambahan unsur hara melalui pupuk anorganik dapat tersedia dalam waktu yang relatif cepat, berbeda dengan sifat pupuk organik yang slow release, sehingga unsur hara yang disumbangkan oleh pupuk organik dan pupuk anorganik tidak terjadi pada waktu yang bersamaan. Hal ini yang diduga menjadi penyebab tidak adanya interaksi nyata antara keduanya. Gardner, Pearce dan Mitchell (1991), menyatakan bahwa adanya nutrisi yang cukup memungkinkan daun muda maupun tua memenuhi kebutuhan nutrisinya, dan nutrisi yang terbatas lebih sering didistribusikan ke daun-daun muda, sehingga mengurangi laju fotosintesa pada daun yang tua. Menurut Yunus (1991), bahwa bahan organik yang dikandung oleh pupuk organik mampu bersatu dan membalut partikel-partikel tanah menjadi butiran-butiran tanah yang lebih besar. Butiran-butiran tanah tersebut mampu 
menyimpan unsur hara anorganik dan menyediakan pada saat tanaman memerlukannya. Selain itu pupuk organik yang diberikan dapat membuat keseimbangan hara di dalam tanah dan meningkatkan mutu fisik tanah dengan membuat tekstur tanah, porositas dan struktur tanah menjadi lebih baik.

Penggunaan pupuk organik dapat meningkatkan produktivitas tanaman semangka secara nyata dibandingkan dengan hanya menggunakan pupuk anorganik (Tabel 1). Hal ini, seperti yang diindikasikan oleh panjang buah dan bobot buah; perlakuan P5 dapat meningkatkan bobot buah secara nyata (tertinggi) yaitu 8.30 ton.ha ${ }^{-1}$ dibandingkan perlakuan P1 tetapi terhadap panjang buah tidak menunjukkan perbedaan yang nyata dibandingkan perlakuan P1 (Tabel 1). Hal yang sama juga terjadi, apabila pupuk organik dan pupuk anorganik yang digunakan dengan perbandingan kandungan yang sesuai. Hal ini diduga, pupuk organik dan perbandingan kandungan antara pupuk organik dan pupuk anorganik yang sesuai, mampu menyediakan unsur hara yang cukup dan seimbang untuk kebutuhan tanaman. Unsur hara yang terdapat pada masing-masing jenis pupuk menjadi pemicu adanya interaksi antara kandungan persentase pupuk organik dan pupuk anorganik. Kondisi yang demikian kemungkinan ada kaitannya dengan kandungan nutrisi maupun hormon tumbuh dalam pupuk organik hayati yang dapat saling menunjang manfaatnya jika dikombinasikan dengan pupuk anorganik. Dilaporkan bahwa Pseudomonas sp., Bacillus sp., dan Streptomyces sp. merupakan mikroba penyubur perakaran yang mampu menyediakan nutrisi dan hormon tumbuh bagi tanaman (Antonius, Nurlaili, Yanti, Arif, Dwi, 2009).

\section{KESIMPULAN}

Aplikasi pupuk organik dan anorganik berpengaruh nyata terhadap panjang buah dan bobot buah, tetapi tidak berpengaruh nyata terhadap daya tumbuh, panjang batang utama dan jumlah daun. Panjang buah terpanjang dijumpai pada perlakuan aplikasi $75 \%$ pupuk anorganik $+25 \%$ pupuk organik (P2). Sedangkan bobot buah terberat dijumpai pada perlakuan aplikasi 100\% pupuk organik (P5).

Daya tumbuh tanaman tertinggi dijumpai pada perlakuan aplikasi $100 \%$ pupuk anorganik (P1), perlakuan aplikasi 50\% pupuk anorganik $+50 \%$ pupuk organik (P3), perlakuan P2 dan P5. Panjang batang utama terpanjang dijumpai pada perlakuan P5, sedangkan jumlah daun terbanyak dijumpai pada perlakuan P2. Aplikasi pupuk organik dan anorganik masih dapat meningkatkan pertumbuhan dan hasil tanaman semangka, sehingga disarankan perlu dilakukan. Aplikasi $75 \%$ pupuk anorganik $+25 \%$ pupuk organik dan aplikasi $100 \%$ pupuk organik dapat dianjurkan sebagai dosis pemupukan tanaman semangka. Aplikasi $75 \%$ pupuk anorganik $+25 \%$ pupuk organik dan aplikasi $100 \%$ pupuk organik dapat untuk diteliti lebih lanjut dengan jenis pupuk organik lainnya.

\section{DAFTAR PUSTAKA}

Antonius S, Nurlaili, Yanti, Arif Nurkanto, Dwi Agustyani. 2009. Eksplorasi dan penapisan mikroba dari malinau sebagai agen hayati pendukung pertanian yang berkelanjutan. Proseding Lingkungan Hidup, Seminar Nasional Biologi XX dan Kongres PBI XIV UIN Maliki Malang, pp: 347-357. 
Nazirwan dan Anung Wahyudi: Interaksi Antara Daya Tumbuh Benih Dengan Pertumbuhan Tanaman...

Ariani, E. 2009. Uji Pupuk NPK Mutiara 16:16:16 dan Berbagi Jenis Mulsa Terhadap Hasil Tanaman Cabai (Capsicum annum L). Jurusan Budidaya Pertanian Fakultas Pertanian Universitas Riau. Pekanbaru. SAGU. 8(1) : 5-9.

Ashari, S. 1995. Semangka. p: 400 - 404. dalam Hortikultura: Aspek Budidaya. Penerbit Universitas Indonesia (UI-PRESS).

Deptan. 2014. Luas Panen, Produksi dan Produktivitas Buah Indonesia, 2008 - 2012. Badan Pusat Statistik dan Direktorat Jenderal Hortikultura. www.deptan.go.id. Diakses tanggal 09 Februari 2014.

Gardner, F.P., R.B. Pearce, dan R.L. Mitchell. 1991. Physiology of Crop Plants (Fisiologi Tanaman Budidaya, alih bahasa: Susilo dan Subiyanto). UI Press, Jakarta.

Hegde, D.M. and B.S, Dwivedi. 1993. Integrated Nutrient Supply and Management as a Strategy To Meet Nutrient Demand In : Fert News. 38: 49-59.

Khan, A.A. 1992. Preplant physiological seed conditioning. Page: 131-181. In Janick (Ed.). Hort. Rev. Wiley \& Sons, Inc., New York.

Mohr, H.C. 1986. Watermelon Breeding. p: 7 - 66. In M.J. Basset (Ed.). Breeding Vegetable Crop. Avi Publishing Company, Inc., Westport, Connecticut.

Murbandono, HSL. 1990. Membuat Kompos. Penebar Swadaya. Jakarta.

Rukmana, R. 1995. Usaha Tani Jagung. Kanisius. Yogyakarta.

Sarief, E.S. 1985. Kesuburan dan Pemupukan Tanah Pertanian. Pustaka Buana. Bandung. 182 Hal.

Setyamidjaja, D. 1986. Pupuk dan Pemupukan. Simplex, Jakarta. 122 hal.

Sudjianto, U dan V. Krestiani. 2009. Studi Pemulsaan dan Dosis NPK pada Hasil Buah Melon (Cucumis melo L). Jurnal Sains dan Teknologi. 2 (2) : 7-18.

Syukur, M. 2014. Semangka Citrullus lanatus (Thunberg) Maksum \& Nakai. YUMKMI-IPBPendahuluan Budidaya Tanaman Semangka. www.ina.or.id/knoma-hpsp/fruit/HPSP-09YUMKMI-Semangka.pdf. Diakses tanggal 11 Februari 2014

Whitaker, T.W. and G.N. Davis. 1962. Cucurbits. Interscience Publisher, Inc., New York.

Yunus, M. 1991. Pengelolaan Limbah Peternakan. Jurusan Produksi Ternak LUW-Universitas Brawijaya. Animal Husbandry Project. p.117. 